\title{
Stelselwijzigingen en het gebruik van jaarrekeningen
}

\section{Een onderzoek onder beleggingsanalisten}

Dr. R.G.A. Vergoossen

1

Inleiding

Op de hedendaagse kapitaalmarkt spelen beleggingsanalisten een belangrijke rol als informatie-intermediairs tussen ondernemingen en beleggers. Om tot een verantwoord oordeel te komen omtrent de door een onderneming in haar jaarrekening of tussentijdse overzichten gepresenteerde financiële positie en behaalde resultaten is een stelselmatige toepassing van de gekozen verslaggevingsgrondslagen van groot belang. Een veel voorkomend verschijnsel in jaarrekeningen van Nederlandse ondernemingen echter is stelselwijziging. Stelselwijzigingen omvatten wijzigingen in de grondslagen van waardering en resultaatbepaling die worden gebruikt bij het opstellen van jaarrekeningen. Stelselwijzigingen betekenen aldus een doorbreking van de stelselmatige toepassing van in het verleden gekozen verslagge vingsgrondslagen. Het inzicht in de ontwikkeling van de financiële positie en behaalde resultaten van de desbetreffende ondernemingen kan daardoor worden vertroebeld.

Uit een onderzoek van Hoogendoorn (1990), die de jaarrekeningen over 1977-1986 van 138 ter beurze van Amsterdam genoteerde Nederlandse ondernemingen bestudeerde, blijkt dat in $29 \%$ van de onderzochte jaarrekeningen één of meer wijzigingen in de grondslagen van waardering en resultaatbepaling zijn doorgevoerd. In $45 \%$ van de jaarrekeningen met één of meer wijzigingen wordt de nettowinst en/of het eigen vermogen materieel beïnvloed. Hoogendoorn bestempelt de informatieverschaffing met betrekking tot $46 \%$ van de materiële wijzigingen als matig tot zeer slecht. Hij uit het sterke vermoeden dat stelselwijzigingen met een materieel effect op het nettoresultaat in het algemeen worden doorgevoerd ter beïnvloe- ding van het gerapporteerde nettoresultaat. Stelselwijzigingen met een winstverhogend effect blijken vooral te worden doorgevoerd door minder succesvolle ondernemingen en in jaren dat het slechter gaat.

In dit artikel wordt verslag gedaan van een onderzoek naar de wijze waarop beleggingsanalisten in hun analyses omgaan met wijzigingen in de grondslagen van waardering en resultaatbepaling. In paragraaf 2 wordt kort ingegaan op het gebruik en het belang van verslaggevingsinformatie in de beleggingsanalyse. Vervolgens wordt in paragraaf 3 eerder verricht soortgelijk onderzoek besproken. Daarna wordt in paragraaf 4 de onderzoeksopzet uit de doeken gedaan. Onderzoeksresultaten worden gepresenteerd in paragraaf 5 en 6 . Paragraaf 7 , ten slotte, bevat een korte slotbeschouwing.

\section{Verslaggevingsinformatie en beleggingsanalyse}

In 1991/92 is het gebruik en het belang van verslaggevingsinformatie in de beleggingsanalyse onderzocht door middel van een schriftelijke enquête onder de leden van de Vereniging van

Dr. R.G.A. Vergoossen studeerde economie aan de Erasmus Universiteit te Rotterdam en accountancy aan de Vrije Universiteit te Amsterdam. Hij promoveerde aan laatstgenoemde universiteit op het proefschrift Accounting Changes and the Use of Financial Statements: A Study among Investment Analysts. $\mathrm{Hij}$ is als manager Vaktechnische Projecten werkzaam bij het directoraat Vaktechniek van het Koninklijk NIVRA. Daarnaast is hij verbonden aan de vakgroep Kosten- en Winstvraagstukken van de Vrije Universiteit. 
Beleggingsanalisten (VBA).' Daarin werd onder meer gevraagd op een vijfpuntsschaal het belang aan te geven van diverse informatiebronnen die beleggingsanalisten in de beleggingsanalyse ter beschikking staan (1: zeer belangrijk, 2: belangrijk, 3: min of meer van belang, 4: niet zo belangrijk, 5: helemaal niet belangrijk). Hetzelfde werd gevraagd ten aanzien van diverse onderdelen van het financiële jaarverslag. gingsanalisten belangrijker vergeleken met beleggingsanalisten die behoren tot de andere twee categorieën. Hierin komt de intermediaire rol naar voren van beleggingsadviseurs die veelal deze rapporten hebben geschreven, hetgeen nog wordt versterkt door de bevinding dat beleggingsadviseurs de financiële jaarverslagen van ondernemingen veel intensiever bestuderen dan portefeuillebeheerders.

Tabel 1: Informatiebronnen en onderdelen van het financiële jaarverslag (in volgorde van belangrijkheid)

\begin{tabular}{|c|c|c|c|}
\hline Informatiebron & Score & Onderdeel financieel jaarverslag & Score \\
\hline Meest recent financieel jaarverslag & 1,406 & Geconsolideerde resultatenrekening & 1,331 \\
\hline Gesprekken met management & 1,623 & Geconsolideerde balans & 1,497 \\
\hline Tussentijdse berichten & 1.794 & Toelichting op jaarrekening & 1.606 \\
\hline Emissieprospecti & 2,069 & Verslag raad van bestuur & 1,909 \\
\hline Persberichten van onderneming & 2,080 & Kasstroomoverzicht & 2,097 \\
\hline Kranten en tijdschriften & 2.097 & Historisch overzicht met kengetallen & 2.217 \\
\hline Macro-economische indicatoren & 2,401 & Vennootschappelijke balans & 2,920 \\
\hline Rapporten van andere analisten & 2.531 & Vennootschappelijke resultatenrekening & 2,937 \\
\hline Bedrijfstakstatistieken & 2,533 & Accountantsverklaring & 3,211 \\
\hline Financiële jaarverslagen uit eerdere jaren & 2,640 & Bericht raad van commissarissen & 3,731 \\
\hline
\end{tabular}

Door beleggingsanalisten wordt het meest recente financiële jaarverslag als de belangrijkste informatiebron gekwalificeerd, gevolgd door gesprekken met het management en tussentijdse berichten. Rapporten van andere beleggingsanalisten. bedrijfstakstatistieken en financiële jaarverslagen uit eerdere jaren beschouwen ze daarentegen als het minst belangrijk (zie tabel 1). Het feit dat het meest recente financiële jaarverslag wordt beschouwd als de belangrijkste informatiebron betekent echter niet dat beleggingsanalisten zich bij de analyse van ondernemingen beperken tot de bestudering van financiële jaarverslagen. Zij zien het meest recente financiële jaarverslag van een onderneming eerder als een noodzakelijke, doch niet voldoende informatiebron.

Uit het onderzoek komt naar voren dat globaal drie categorieën beleggingsanalisten kunnen worden onderscheiden, namelijk beleggingsanalisten die zich vooral bezighouden met het geven van beleggingsadviezen, portefeuillebeheerders en directeuren/afdelingshoofden. De intensiteit waarmee de financiële jaarverslagen van ondernemingen worden bestudeerd, verschilt per categorie. Het blijkt dat beleggingsadviseurs de meest intensieve gebruikers van financiële jaarverslagen zijn. Portefeuillebeheerders vinden in de uitoefening van hun functie rapporten van andere beleg-
Voor wat betreft de verschillende onderdelen van het financiële jaarverslag, blijkt dat beleggingsanalisten de geconsolideerde winst- en verliesrekening het belangrijkst achten, gevolgd door de geconsolideerde balans en de toelichting op de jaarrekening. De accountantsverklaring en het bericht van de raad van commissarissen worden het minst belangrijk geacht (zie tabel 1). Directeuren/afdelingshoofden vinden het verslag van de raad van bestuur belangrijker vergeleken met beleggingsadviseurs en portefeuillebeheerders. Een mogelijke verklaring hiervoor is dat directeuren/afdelingshoofden het financiële jaarverslag vooral gebruiken als algemene oriëntatie op ondernemingen.

Als belangrijkste informatie-elementen in de toelichting op de jaarrekening worden aangemerkt de toegepaste grondslagen van waardering en resultaatbepaling, eventuele wijzigingen in de grondslagen en de invloed van deze wijzigingen op de gepresenteerde cijfers. De verschillen met andere informatie-elementen, zoals naar bedrijfstak gesegmenteerde omzetcijfers, zijn evenwel niet significant. Beleggingsadviseurs vinden informatie over stelselwijzigingen belangrijker dan portefeuillebeheerders, hetgeen in overeenstemming is met de bevinding dat beleggingsadviseurs vergeleken met portefeuillebeheerders de financiële jaarverslagen intensiever bestuderen. Een groot deel van de 
beleggingsanalisten kwalificeert de informatie die met betrekking tot stelselwijzigingen in de financiële jaarverslagen van Nederlandse ondernemingen wordt verstrekt als matig of slecht.

Voor een uitgebreide bespreking van het onderzoek en de onderzoeksresultaten zie Vergoossen (1993; 1994, hoofdstuk 5). De onderzoeksresultaten zijn in grote lijnen in overeenstemming met eerdere gelijksoortige onderzoeken in het buitenland (zie onder meer Chang \& Most, 1985).

\section{Eerder verricht onderzoek}

Eerdere studies naar de invloed van stelselwijzigingen op de oordeels- c.q. besluitvorming van gebruikers van jaarrekeningen kunnen worden gekwalificeerd als kapitaalmarktonderzoek of gebruikersonderzoek. In kapitaalmarktonderzoek staat het effect van stelselwijzigingen op aandelenkoersen centraal, dat wil zeggen het gedrag van de collectiviteit van aandeelhouders is onderwerp van studie. In gebruikersonderzoek daarentegen wordt de invloed van stelselwijzigingen op de oordeels- of besluitvorming van individuele gebruikers onderzocht. Gebruikersonderzoek heeft, in tegenstelling tot kapitaalmarktonderzoek, slechts op zeer beperkte schaal plaatsgevonden.

In beginsel zouden wijzigingen in de grondslagen van waardering en resultaatbepaling niet mogen leiden tot wijzigingen in de oordeels- c.q. besluitvorming van gebruikers, omdat de achterliggende economische omstandigheden doorgaans niet zullen veranderen. Alleen wanneer stelselwijziging leidt tot mutaties in de kasstromen of tot additionele informatie omtrent het reilen en zeilen van de onderneming, kunnen wijzigingen in het gebruikersgedrag als rationeel worden bestempeld. Mutaties in de kasstromen kunnen zich voordoen wanneer een stelselwijziging in de bedrijfseconomische jaarrekening samengaat met een overeenkomstige wijziging in de fiscale jaarrekening. In dat geval immers zouden zich mutaties in de belastingbetalingen kunnen voordoen.

\section{Kapitaalmarktonderzoek}

De resultaten van de studies naar de invloed van stelselwijzigingen op aandelenkoersen zijn niet eenduidig, met name als gevolg van methodologische tekortkomingen. Onder meer om de navolgende redenen is het vaak niet goed mogelijk het effect van stelselwijzigingen op aandelenkoersen te isoleren:

- ondernemingen die slechter presteren zijn over het algemeen eerder geneigd stelselwijzigingen met een winstverhogend effect door te voeren;

- er kan sprake zijn van clustering van een bepaalde stelselwijziging in een bepaalde periode of bedrijfstak;

- de bekendmaking van stelselwijzigingen gaat vaak gepaard met de bekendmaking van jaarof kwartaalcijfers;

- er kan sprake zijn van 'verborgen' kasstroomeffecten. Zo zouden wijzigingen in de grondslagen van waardering en resultaatbepaling invloed kunnen hebben op de bezoldiging van bestuurders of op leningsvoorwaarden.

Aldus is het bijvoorbeeld mogelijk dat een waargenomen marktreactie niet het gevolg is van stelselwijziging, maar van de afwijkende prestaties van ondernemingen die een stelselwijziging hebben doorgevoerd vergeleken met andere ondernemingen. Omgekeerd betekent het ontbreken van een marktreactie niet zonder meer dat aandelenkoersen niet worden beïnvloed door stelselwijziging; er kan immers sprake zijn van elkaar compenserende effecten.

In sommige studies worden de onderzoeksresultaten gezien als een bevestiging van de semisterke variant van de efficiënte markthypothese, dat wil zeggen dat de 'markt' stelselwijzigingen doorziet (zie onder meer Ball, 1972; Kaplan \& Roll, 1972: Biddle \& Lindahl, 1982; Stevenson, 1987). In andere studies daarentegen is van een dergelijke bevestiging geen sprake (zie onder meer Archibald, 1972; Abdel-khalik \&

McKeown, 1978; Ricks, 1982).

\section{Gebruikersonderzoek}

Gebruikersonderzoek onder beleggingsanalisten is niet alleen van belang vanwege de tegenstrijdige resultaten van het kapitaalmarktonderzoek, maar ook omdat de intensiteit en kwaliteit van de beleggingsanalyse een belangrijke bepalende factor is van de mate van efficiëntie van de kapitaalmarkt.

Eerdere studies naar de invloed van stelselwijzigingen op de oordeels- of besluitvorming van individuele beleggingsanalisten zijn uitgevoerd in de vorm van gecontroleerde experimenten door Abdel-khalik \& Keller (1979) en Feenstra (1985). In genoemde studies werden beleggingsanalisten geconfronteerd met een aantal cases en vraagstel- 
lingen die op een zodanige manier waren geconstrueerd dat achteraf kon worden getraceerd in hoeverre hun oordeels- en besluitvorming werd beïnvloed door stelselwijzigingen.

In de studie van Abdel-khalik \& Keller betrof het een wijziging van het 'first-in first-out' (FIFO) systeem naar het 'last-in first-out' (LIFO) systeem van voorraadwaardering. Toepassing van de LIFO-methode zal in tijden van inflatie leiden tot een winst die lager is dan bij toepassing van de FIFO-methode het geval zou zijn. Voor ondernemingen zou het aldus voordelig kunnen zijn om in de fiscale jaarrekening de LIFO-methode toe te passen en in de bedrijfseconomische jaarrekening de FIFO-methode. In de Verenigde Staten - het land waarin onderhavig onderzoek is uitgevoerd is toepassing van de LIFO-methode ter bepaling van de fiscale winst evenwel slechts toegestaan wanneer deze methode ook wordt toegepast in de bedrijfseconomische jaarrekening. Dus ondernemingen die overstappen van het FIFO- op het LIFO-systeem van voorradwaardering genereren een positief kasstroomeffect (er wordt immers minder belasting betaald) en rapporteren een lagere winst. Abdel-khalik \& Keller stelden vast dat de in het onderzoek betrokken beleggingsanalisten een duidelijke voorkeur hadden voor ondernemingen die de FIFO-methode toepasten. $\mathrm{Zij}$ concludeerden dan ook dat de beleggingsanalisten waren gefixeerd op de nettowinst (p. 47):

"Those participants in the sample were greatly influenced by reported earnings and negatively influenced by the impact of the suitch to LIFO on reported earnings even when they were told and were shown the positive impact of the switch decision on net cash inflows. To this end, the results show that participants appear to be functionally fixated on using reported earnings to form expectations, even if such reported numbers are artificially depressed in a significant way."

In Nederland is een soortgelijke studie verricht door Feenstra. In tegenstelling tot Abdel-khalik \& Keller werd door Feenstra in het algemeen geen fixatie waargenomen. Dit zou onder meer een gevolg kunnen zijn van het feit dat veel beleggingsanalisten de ondernemingen herkenden waarop de in de cases verstrekte gegevens betrekking hadden. Hierdoor is het mogelijk dat zij zich meer hebben laten leiden door hun (voor)oordelen omtrent de desbetreffende ondernemingen dan door de verstrekte gegevens.
Over het algemeen is de interne validiteit van experimenten hoog, dat wil zeggen afhankelijke en onafhankelijke variabelen zijn op een dusdanige manier geschikt dat eenduidig de invloed kan worden vastgesteld van de manipulatie van een bepaalde onafhankelijke variabele (de methode van voorraadwaardering bijvoorbeeld) op de afhankelijke variabele (de aanbevelingen van beleggingsanalisten). Het zal duidelijk zijn dat de interne validiteit van de studie van Abdel-khalik $\&$ Keller hoger is dan die van Feenstra.

De externe validiteit van experimenten - dat is de algemene geldigheid van de conclusies - kan echter worden aangetast als de deelnemende beleggingsanalisten niet handelen conform de werkelijkheid. Dit kan zich voordoen wanneer het realiteitsgehalte van de experimenten te wensen overlaat of wanneer beleggingsanalisten niet serieus deelnemen aan het onderzoek. De problemen ten aanzien van de externe validiteit doen zich niet voor bij veldonderzoek. In een veldonderzoek onder beleggingsanalisten namelijk registreert de onderzoeker het gedrag van beleggingsanalisten zoals dat zich in werkelijkheid voordoet. Hieronder wordt verslag gedaan van de opzet en de resultaten van een dergelijk onderzoek. ${ }^{2}$

\section{Onderzoeksopzet}

In dit onderzoek zijn beleggingsanalisten werkzaam bij gerenommeerde banken en effectenhuizen en financieel journalisten werkzaam bij een viertal financiële bladen betrokken. ${ }^{3}$ Onderwerp van studie zijn de door deze beleggingsanalisten en financieel journalisten opgestelde financiële analyserapporten respectievelijk artikelen in de financiële pers. In het vervolg van dit artikel omvat de term 'beleggingsanalisten' tevens de in het onderzoek betrokken financieel journalisten en de term 'analyserapporten' tevens de onderzochte artikelen in de financiële pers, tenzij anders vermeld.

In totaal zijn ongeveer 600 analyserapporten onderzocht. De analyserapporten hebben betrekking op twaalf beursgenoteerde ondernemingen die in de periode 1987-1991 zestien stelselwijzigingen hebben doorgevoerd met een belangrijke invloed op de gepresenteerde cijfers. ${ }^{4}$ Het betreft de navolgende ondernemingen met tussen haakjes de jaren waarin de stelselwijzigingen zijn doorgevoerd:

- Bührmann-Tetterode NV (1990);

- NV Centrale Suiker Maatschappij (1988/89); 
- Elsevier NV (1989);

- Koninklijke Gist-brocades NV (1991);

- Koninklijke Luchtvaart Maatschappij NV (1989/90);

- Koninklijke Nederlandse Papierfabrieken NV (1987, 1988 en 1991);

- NV Koninklijke Nederlandse Vliegtuigenfabriek Fokker (1989);

- Pakhoed Holding NV (1989);
- NV Philips` Gloeilampenfabrieken (1989: twee stelselwijzigingen);

- Unilever NV (1990);

- NV Verenigd Bezit VNU (1989 en 1990);

- Wolters Kluwer NV (1990).

De invloed van onderhavige stelselwijzigingen op het door ondernemingen gepresenteerde nettoresultaat en/of eigen vermogen liep sterk uiteen (zie tabel 2).

Tabel 2: Stelselwijzigingen en fixatie van beleggingsanalisten

\begin{tabular}{|c|c|c|c|c|c|c|c|c|}
\hline \multirow{2}{*}{$\begin{array}{l}\text { Stelselwijziging (naam van } \\
\text { onderneming en jaar van } \\
\text { stelselwijziging) }\end{array}$} & \multirow{2}{*}{$I_{d}$} & \multicolumn{2}{|c|}{ Effect $(\%)$ op } & \multirow{2}{*}{$n$} & \multicolumn{3}{|c|}{ Fixatie } & \multirow{2}{*}{$I$} \\
\hline & & resultaat & vermogen & & sterk & $z w a k$ & geen & \\
\hline \multicolumn{9}{|l|}{ WIR-premies: } \\
\hline KNP 1987 & 0,833 & 43,3 & n.v.t. & 12 & 1 & 5 & 6 & 0,292 \\
\hline CSM $1988 / 89$ & 0,200 & $-/-6,8$ & 1,2 & 14 & 9 & 1 & 4 & 0,679 \\
\hline Fokker 1989 & 0,100 & 15,2 & n.v.t. & 22 & 16 & 5 & 1 & 0,841 \\
\hline Pakhoed 1989 & 0,800 & 7,4 & n.v.t. & 13 & 3 & 0 & 10 & 0,231 \\
\hline VNU 1990 & 0,800 & 20.4 & n.v.t. & 23 & 3 & 0 & 20 & 0,130 \\
\hline \multicolumn{4}{|c|}{ Subtotaal stelselwijzigingen WIR-premies } & 84 & 32 & 11 & 41 & 0,446 \\
\hline \multicolumn{9}{|l|}{ Uitgaverechten: } \\
\hline Elsevier 1989 & 1,000 & n.v.t. & 46,9 & 20 & 4 & 4 & 12 & 0,300 \\
\hline VNU 1989 & 1,000 & n.v.t. & 63,8 & 13 & 3 & 1 & 9 & 0,269 \\
\hline Wolters Kluwer 1990 & 0,833 & n.v.t. & 86,4 & 15 & 5 & 1 & 9 & 0,367 \\
\hline \multicolumn{4}{|c|}{ Subtotaal activeren uitgaverechten } & 48 & 12 & 6 & 30 & 0,313 \\
\hline
\end{tabular}

Actuele waarde/historische

kosten:

\begin{tabular}{|c|c|c|c|c|c|c|c|c|}
\hline KNP 1988 & 1,000 & 11,5 & n.v.t. & 11 & 0 & 4 & 7 & 0,182 \\
\hline Bührmann-Tetterode 1990 & 1.000 & 4,0 & n.v.t. & 14 & 2 & 0 & 12 & 0,143 \\
\hline Gist-brocades 1991 & 1,000 & 2,6 & $-/-13,6$ & 15 & 2 & 7 & 6 & 0,367 \\
\hline \multicolumn{4}{|c|}{ Subtotaal wijzigingen actuele waarde/historische kosten } & 40 & 4 & 11 & 25 & 0,238 \\
\hline \multicolumn{9}{|l|}{ Overige: } \\
\hline Philips(a) 1989 & 0,600 & 14,0 & n.v.t. & 15 & 9 & 2 & 4 & 0,667 \\
\hline Philips(b) 1989 & 0,500 & 6,4 & n.v.t. & 15 & 12 & 2 & 1 & 0,867 \\
\hline KLM 1989/90 & 1,000 & 16,1 & n.v.t. & 11 & 2 & 1 & 8 & 0,227 \\
\hline Unilever 1990 & 1,000 & 6,7 & n.v.t. & 19 & 0 & 9 & 10 & 0,237 \\
\hline KNP 1991 & 0,800 & 14,9 & n.v.t. & 19 & 0 & 0 & 19 & 0,000 \\
\hline \multicolumn{4}{|c|}{ Subtotaal overige stelselwijzigingen } & 79 & 23 & 14 & 42 & 0,380 \\
\hline \multicolumn{4}{|l|}{ Totaal } & 251 & 71 & 42 & 138 & 0,367 \\
\hline
\end{tabular}

$I_{d}=$ informatieverschaffingsindex

$I_{\mathrm{f}}=$ fixatie-index

$\mathrm{n}=$ totaal aantal beleggingsanalisten waarvan analyserapporten zijn onderzocht

Toelichting overige stelselwijzigingen: de stelselwijzigingen van Philips hebben betrekking op (a) de kosten voor pensioenaanspraken respectievelijk (b) de financieringscorrectie in landen met hyperinflatie. De stelselwijziging van KLM betreft de verwerking van koersverschillen en die van Unilever de omrekening van vreemde valuta's. De stelselwijziging van KNP heeft betrekking op de voorziening voor latente belastingen. 
De mate van informatieverschafting in de desbetreffende jaarrekeningen is verschillend. Om dit tot uitdrukking te brengen is voor iedere stelselwijziging een informatieverschaffingsindex $\left(I_{d}\right)$ berekend. Dalarbij is nagegaan of al dan niet expliciet informatic wordt verstrekt omtrent:

1 hel feit dat een stelselwijziging is doorgevoerd:

2 de verschillen tussen het oude en het nieuwe stelsel;

3 de redenen van de stelselwijziging:

4 het cumulatieve effect van de stelselwijziging;

5 het effect van de stelselwijziging op resultaat en vermogen in het jaar van stelselwijziging;

6 de aanpassing van de vergelijkende cijfers.'

Bij de berekening van de inlormatieverschaffingsindices is de navolgende formule gehanteerd:

$$
I_{4}=\frac{\sum_{i=1}^{6} R_{1} V_{1}}{\sum_{i=1}^{6}}
$$

$R_{1}=\begin{aligned} & 1 \text { indien van toepassing } \\ & 0 \text { indien niet van toepassing }\end{aligned}$

$V_{1}=\begin{aligned} & 1 \text { indien verstreht } \\ & 0 \text { indien niet verstrekt }\end{aligned}$

1-6: informatic-elementen inzake stelselwijziging

De informatieverschaffingsindex kan variëren van 0.0 (er wordt geen enkele informatie omtrent de stelselwijziging verstrekt) tot 1.0 (de informatieverschaffing omtrent de stelselwijziging is volledig). In tabel 2 is voor iedere stelselwijziging de informatieverschaffingsindex opgenomen.

Aan de hand van de analyserapporten is onderzocht in welke mate beleggingsanalisten zijn gefixeerd op winst- en/of vermogenscijfers die door de stelselwijzigingen zijn beïnvloed. Daarbij is een onderscheid gemaakt tussen een sterke mate van fixaltie en een zwakke mate van fixatie:

- beleggingsanalisten die in hun analyserapporten in het geheel niet signaleren dat een stelselwijziging is doorgevoerd, worden geacht in sterke mate te zijn gefixeerd:

- beleggingsanalisten die in hun analyserapporten wel melding maken van het feit dat een stelselwijziging is doorgevoerd. maar daarbij niet ingaan op de effecten van de desbetreffende stelselwijziging op de winst- en/of vermogenscijfers worden geacht in zwakke mate te zijn gefixeerd.

Beleggingsanalisten worden geacht niet te zijn gefixeerd wanneer de effecten van een stelselwijziging op de winst- en/of vermogenscijfers in de analyserapporten uit de doeken worden gedaan.

Voor de goede orde zij vermeld dat wanneer een beleggingsanalist in zijn analyserapport(en) in het geheel geen melding maakt van de stelselwijziging en dus volgens bovenstaande definitie in sterke mate is gefixeerd, dat niet noodzakelijkerwijs impliceert dat hij de stelselwijziging niet heeft opgemerkt en diar in zijn oordeelsvorming geen rekening mee heeft gehouden. Het niet melden van de stelselwijziging c.q. hel achterwege laten van een bespreking van de stelselwijziging kan immers een bewuste keuze zijn van de desbetreffende beleggingsanalist. Om te achterhalen of er sprake is van een bewuste keuze moet het oordeelsvormingsproces worden onderzocht. Aan de hand van de analyserapporten - de uitkomsten van dit proces - is dat evenwel niet mogelijk.

In totaal kon met behulp van de analyserapporten in 251 gevallen het fixatieniveau van beleggingsanalisten worden bepaald. dat is gemiddeld 16 beleggingsanalisten per stelselwijziging. Het aantal beleggingsanalisten per stelselwijziging varieerde van 11 tot 27. Zoals hiervoor reeds aangegeven zijn in totaal ongeveer 600 analyserapporten onderzocht. In vele gevallen was het namelijk nodig om van een bepaalde beleggingsanalist meer dan één analyserapport te bestuderen ter bepaling van zijn fixatieniveau. Dit hing samen met het feit dat ondernemingen stelselwijzigingen vaak ruim van te voren aankondigen. bijvoorbeeld in de jaarrekening van het voorafgaande verslagjaar. Om te bepalen in welke mate stelselwijzigingen door beleggingsanalisten worden gesignaleerd en besproken, moesten in dergelijke gevallen alle analyserapporten worden bestudeerd die zijn gepubliceerd vanaf het moment van de eerste aankondiging tot en met de uiteindelijke informalieverschaffing omtrent de feitelijke doorvoering van de stelselwijziging in de jaarrekening.

Aan de hand van de analyserapporten is onderzocht of het fixatieniveau van beleggingsanalisten athankelijk is van de navolgende vier factoren:

1 de mate waarin een onderneming in haar jaarrekening informatie verschaft ten aanzien van de doorgevoerde stelselwijziging, 
2 het moment waarop de stelselwijziging voor het eerst wordt aangekondigd c.q. bekendgemaakt,

3 de aard van de stelselwijziging en

4 de werkgever van de beleggingsanalist. ${ }^{6}$

\section{Onderzoeksresultaten}

In 71 van de 251 gevallen ( $28 \%$ ) bleken beleggingsanalisten in sterke mate te zijn gefixeerd en in 42 gevallen (17\%) in zwakke mate. In de resterende 138 gevallen (55\%) bleken beleggingsanalisten niet te zijn gefixeerd, dat wil zeggen de invloed van de stelselwijziging op de winst- en/of vermogenscijfers werd expliciet in de analyserapporten besproken. Op basis van de fixatieniveaus van de in het onderzoek betrokken beleggingsanalisten is voor elke stelselwijziging een fixatie-index $\left(I_{f}\right)$ berekend (zie tabel 2). Daarbij is de navolgende formule gehanteerd:

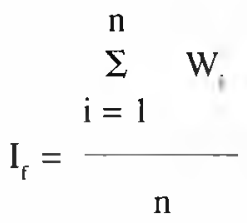

1,0 wanneer in sterke mate gefixeerd $\mathrm{W}_{i}=0,5$ wanneer in zwakke mate gefixeerd 0,0 wanneer niet gefixeerd

$\mathrm{n}$ : totaal aantal beleggingsanalisten

De fixatie-indices, die een indicatie geven van de mate van fixatie met betrekking tot de diverse stelselwijzigingen, blijken aanmerkelijk te verschillen. Een fixatie-index van 0,0 betekent dat geen enkele beleggingsanalist in sterke of zwakke mate is gefixeerd, terwijl een fixatie-index van 1,0 betekent dat alle beleggingsanalisten in sterke mate zijn gefixeerd.

Hierna volgt een bespreking van de in de vorige paragraaf genoemde mogelijke determi- nanten van het fixatieniveau van beleggingsanalisten.

\section{Mate van informatieverschaffing}

Voor wat betreft de informatieverschaffing omtrent de stelselwijzigingen, is onderscheid gemaakt tussen een hoge mate van informatieverschaffing (de informatieverschaffingsindex is 0,8 of hoger) en een lage mate van informatieverschaffing (de informatieverschaffingsindex is lager dan 0,8 ). Een informatieverschaffingsindex van 0,8 of hoger betekent dat de informatieverschaffing in de jaarrekening volledig of vrijwel volledig is.

De stelselwijzigingen CSM 1988/89, Fokker 1989. Philips 1989(a) en Philips 1989(b) hebben een informatieverschaffingsindex van $0,2,0,1,0,6$ en 0,5 . Bij de overige stelselwijzigingen is er in de jaarrekening sprake van een hoge mate van informatieverschaffing. In tabel 3 is voor beide categorieën aangegeven hoeveel beleggingsanalisten in sterke mate zijn gefixeerd en hoeveel beleggingsanalisten niet in sterke mate zijn gefixeerd. Ten behoeve van de $\chi^{2}$-toets zijn de als zwak of niet-gefixeerd gekwalificeerde beleggingsanalisten samengevoegd.

De resultaten van de $\chi^{2}$-toets geven aan dat er een statistisch significant verband bestaat tussen de mate van informatieverschaffing en het fixatieniveau van beleggingsanalisten $(p<0,05)$. Ook wanneer rekening wordt gehouden met de aard van stelselwijziging - een andere determinant van het fixatieniveau (zie hierna) - is er sprake van een statistisch significant verband $\left(\chi^{2}\right.$ met continuïteitscorrectie: 23,979; p: 0,000). Aldus blijkt de kwaliteit van de informatieverschaffing omtrent stelselwijzigingen een determinant van het fixatieniveau van beleggingsanalisten te zijn.

\section{Moment van aankondiging}

Om te beoordelen of het moment van aankondiging c.q. bekendmaking een verklarende factor

Tabel 3: Mate van informatieverschaffing en fixatieniveau

\begin{tabular}{|c|c|c|c|}
\hline & $\begin{array}{r}\text { Fixatieniveau } \\
\text { sterk }\end{array}$ & $\begin{array}{r}\text { Fixatieniveau } \\
\text { niet sterk }\end{array}$ & Totaal \\
\hline Mate van informatieverschaffing hoog & 25 & 160 & 185 \\
\hline Mate van informatieverschaffing laag & 46 & 20 & 66 \\
\hline Totaal & 71 & 180 & 251 \\
\hline
\end{tabular}


is voor het fixatieniveau van beleggingsanalisten, is een onderscheid gemaakt tussen stelselwijzigingen die (ruim) één jaar vóór publikatie van de jaarrekening, waarin de stelselwijziging feitelijk is doorgevoerd, worden aangekondigd en stelselwijzigingen die in de desbetreffende jaarrekening zelf of kort daarvoor bij de publikatie van de voorlopige of definitieve jaarcijfers worden bekendgemaakt.

De stelselwijzigingen Fokker 1989, Wolters Kluwer 1990, KNP 1988, Bührmann-Tetterode 1990 en Gist-brocades 1991 zijn (ruim) één jaar vóór publikatie van de jaarrekening aangekondigd. $\mathrm{Bij}$ de overige stelselwijzigingen is dat niet het geval.

Het zou zijn te verwachten dat het fixatieniveau van beleggingsanalisten met betrekking tot stelselwijzigingen die ruim van tevoren worden aangekondigd lager is dan met betrekking tot stelselwijzigingen die later worden bekendgemaakt. In het eerste geval worden beleggingsanalisten vaker met de stelselwijziging geconfronteerd. namelijk op het moment van aankondiging zelf maar veelal ook in daaropvolgende publikaties van tussentijdse cijfers. Zoals uit tabel 4 blijkt, is het verband tussen het moment van aankondiging en het fixatieniveau van beleggingsanalisten statistisch niet significant $(p>0,05)$.
2 het activeren van uitgaverechten. Het betreft hier de stelselwijzigingen Elsevier 1989, VNU 1989 en Wolters Kluwer 1990. Deze stelselwijzigingen hebben geen invloed op de gepresenteerde winstcijfers, doordat op de uitgaverechten in principe niet wordt afgeschreven;

3 het overstappen van waardering tegen actuele waarde op waardering tegen historische kosten. KNP 1988, Bührmann-Tetterode 1990 en Gist-brocades 1991 worden tot deze categorie gerekend;

4 overige stelselwijzigingen. Het betreft hier de stelselwijzigingen Philips 1989(a), Philips 1989(b), KLM 1989/90, Unilever 1990 en KNP 1991 (zie tabel 2 voor een toelichting op de aard van deze stelselwijzigingen).

In tabel 5 (zie volgende pagina) komt naar voren dat er een statistisch significant verband bestaat tussen de aard van de stelselwijziging en het fixatieniveau van beleggingsanalisten $(p<0,05)$. Dit is ook het geval wanneer rekening wordt gehouden met de mate van informatieverschaffing $\left(\chi^{2}: 9,618 ; p: 0,022\right)$. De mate van informatieverschaffing is eveneens een verklarende factor voor het fixatieniveau van beleggingsanalisten (zie hiervoor). ${ }^{\text {? }}$

Het percentage sterk gefixeerde beleggingsanalisten met betrekking tot het activeren van uitgave-

Tabel 4: Moment van aankondiging en fixatieniveau

\begin{tabular}{lrrr}
\hline & Fixatieniveau & Fixatieniveau & Totaal \\
sterk & 25 & 52 & 77 \\
\hline Moment van aankondiging vroeg & 46 & 128 & 174 \\
Moment van aankondiging laat & 71 & 180 & 251 \\
Totaal & & & \\
\hline$\chi^{2}$ met continuiteitscorrectie: $0.683 ; p: 0,409$ & &
\end{tabular}

\section{Aard van stelselwijziging}

Om te toetsen of er een verband bestaat tussen de aard van de stelselwijziging en het fixatieniveau van beleggingsanalisten zijn de navolgende vier soorten stelselwijzigingen onderscheiden: 1 stelselwijzigingen met betrekking tot de verwerking van investeringspremies (WIR), bijvoorbeeld het versneld ten gunste van het resultaat laten vrijvallen van op een egalisatierekening verantwoorde WIR-premies. KNP 1987, CSM 1988/89, Fokker 1989 , Pakhoed 1989 en VNU 1990 behoren tot deze categorie; rechten is relatief hoog $(25 \%)$. Een mogelijke verklaring hiervoor is dat deze stelselwijziging uitsluitend invloed heeft op de hoogte van het gepresenteerde eigen vermogen. Over het algemeen staan in de beleggingsanalyse winstcijfers centraal en wordt aan vermogenscijfers minder aandacht besteed. Het percentage sterk gefixeerde beleggingsanalisten met betrekking tot het overstappen van waardering tegen actuele waarde op waardering tegen historische kosten is daarentegen relatief laag $(10 \%)$. Dit is waarschijnlijk een gevolg van het min of meer fundamentele karakter van deze 


\begin{tabular}{|c|c|c|c|}
\hline & $\begin{array}{r}\text { Fixatieniveau } \\
\text { sterk }\end{array}$ & $\begin{array}{r}\text { Fixatieniveau } \\
\text { niet sterk }\end{array}$ & Totaal \\
\hline Verwerking WIR-premies & 32 & 52 & 84 \\
\hline Activeren van uitgaverechten & 12 & 36 & 48 \\
\hline Actuele waarde/historische kosten & 4 & 36 & 40 \\
\hline Overige stelselwijzigingen & 23 & 56 & 79 \\
\hline Totaal & 71 & 180 & 251 \\
\hline
\end{tabular}

stelselwijziging. De percentages sterk gefixeerde beleggingsanalisten met betrekking tot de andere twee categorieën worden vertekend doordat daarin stelselwijzigingen met een lage mate van informatieverschaffing zijn opgenomen. Indien hiervoor wordt gecorrigeerd, bedragen de percentages 15 en 4 voor respectievelijk de stelselwijzigingen met betrekking tot de verwerking van WIR-premies en de overige stelselwijzigingen.

\section{Werkgever van beleggingsanalist}

Zoals hiervoor reeds besproken, zijn in het onderzoek twee categorieën beleggingsanalisten betrokken, namelijk beleggingsanalisten werkzaam bij banken en effectenhuizen en financieel journalisten werkzaam bij een viertal financiële bladen. Tot eerstgenoemde categorie behoren onder meer beleggingsanalisten werkzaam bij de ABN Bank, Amro Bank, Bank Mees \& Hope, CLN Oyens \& Van Eeghen, NMB Bank, Pierson Heldring \& Pierson, Van Meer James Capel en Williams de Broë en tot laatstgenoemde categorie behoren financieel journalisten werkzaam bij Het Financieele Dagblad, Beleggers Belangen, Weekblad Beleggings Expres en De Financieele Koerier.

Hoewel de fixatieniveaus van beide categorieen statistisch niet significant van elkaar blijken te verschillen (zie tabel 6), komt uit het onderzoek naar voren dat financieel journalisten stelselwijzi- gingen over het algemeen uitgebreider bespreken dan beleggingsanalisten werkzaam bij banken en effectenhuizen. Dit houdt mogelijk verband met de omstandigheid dat financieel journalisten hun artikelen met name schrijven voor particuliere (niet-professionele) beleggers, terwijl de analyserapporten van beleggingsanalisten werkzaam bij banken en effectenhuizen vooral ook zijn geschreven voor personen werkzaam bij professionele beleggers.

De gemiddelde fixatie-index van beleggingsanalisten werkzaam bij banken en effectenhuizen bedraagt 0,39 en die van financieel journalisten 0,31 . Hoewel het verschil tussen beide categorieën klein is, blijken binnen de twee categorieën tamelijk grote verschillen te bestaan. Binnen de categorie beleggingsanalisten werkzaam bij banken en effectenhuizen varieert de fixatie-index van 0,30 (Van Meer James Capel) tot 0,72 (Williams de Broë) en binnen de categorie financieel journalisten van 0,09 (Het Financieele Dagblad) tot 0,47 (De Financieele Koerier). In Het Financieele Dagblad worden ten aanzien van 14 van de 16 in het onderzoek betrokken stelselwijzigingen de effecten op de winst- en/of vermogenscijfers besproken en wordt één stelselwijziging gesignaleerd zonder dat daarbij wordt ingegaan op de cijfermatige effecten. In Het Financieele Dagblad blijft aldus slechts één stelsel-

Tabel 6: Werkgever van beleggingsanalist en fixatieniveau

\begin{tabular}{|c|c|c|c|}
\hline & $\begin{array}{r}\text { Fixatieniveau } \\
\text { sterk }\end{array}$ & $\begin{array}{r}\text { Fixatieniveau } \\
\text { niet sterk }\end{array}$ & Totaal \\
\hline Banken/effectenhuizen & 55 & 134 & 189 \\
\hline Financiële pers & 16 & 46 & 62 \\
\hline Totaal & 71 & 180 & 251 \\
\hline
\end{tabular}


wijziging onopgemerk1. De opvallend lage fixatie-index van de journalisten van Het Financieele Dagblad heeft waarschijnlijk te maken met de voorlichtende functie van het blad. De drie beleggersbladen hebben vooral een adviserende functie.

\section{Enkele stelselwijzigingen nader beschouwd}

Zoals besproken in paragraaf 4 zijn ter bepaling van het fixatieniveau van beleggingsanalisten alle analyserapporten in ogenschouw genomen die zijn gepubliceerd vanaf de eerste aankondiging c.q. bekendmaking van de stelselwijziging tot en met de informatieverschaffing omtrent de feitelijke doorvoering van de stelselwijziging in de jaarrekening. Aldus is het fixatieniveau van de beleggingsanalisten bepaald ná publikatie van de desbetreffende jaarrekening. Om die reden en omdat de mate van informatieverschaffing een belangrijke determinant is van het fixatieniveau van beleggingsanalisten. is het interessant om te onderzoeken hoe beleggingsanalisten omgaan met incomplete of inadequate informatieverschaffing omtrent stelselwijzigingen bij de publikatie van voorlopige en/of definitieve jaarcijfers die voorafgaat aan de publikatie van de officiële jaarrekening waarin de uiteindelijke informatieverschaffing omtrent stelselwijzigingen als volledig of vrijwel volledig kan worden aangemerkt. Vooral de analyserapporten van beleggingsanalisten die in dit artikel als niet-gefixeerd worden gekwalificeerd zijn daarbij van belang. Bestudering van de door deze beleggingsanalisten bij de publikatie van voorlopige en/of definitieve jaarcijfers uitgebrachte analyserapporten in combinatie met de analyserapporten uitgebracht naar aanleiding van de publikatie van de officiële jaarrekening kan namelijk inzicht geven in hoeverre de oordeelsvorming van beleggingsanalisten kan worden beïnvloed door een incomplete informatieverschaffing omtrent stelselwijzigingen. Illustratief in dit kader zijn de stelselwijzigingen KNP 1987. VNU 1990 en KLM 1989/90.

\section{KNP 1987}

De stelselwijziging van KNP in haar jaarrekening over 1987 heeft betrekking op de verwerking van WIR-premies. Als gevolg van de stelselwijzi- ging is het gepresenteerde nettoresultaat over 1987 ruim $43 \%$ hoger (zie tabel 2). Het effect van de stelselwijziging is tweeledig, namelijk een jaareffect van $9 \%$ en een cumulatief effect van $34 \%$. Als gevolg van het jaareffect is het resultaat uit gewone bedrijfsuitoefening na belastingen eveneens $9 \%$ hoger. Het cumulatieve effect wordt verantwoord als een buitengewone bate.

In januari 1988 bij de bekendmaking van de voorlopige jaarcijfers kondigde KNP de stelselwijziging aan. Daarbij werd slechts een indicatie gegeven van het cumulatieve effect van de stelselwijziging. De definitieve jaarcijfers werden in maart 1988 gepubliceerd, gevolgd door de officiële jaarrekening enkele weken later. De informatieverschaffing omtrent de stelselwijziging was in deze stukken vrijwel volledig.

Dat de hiervoor beschreven wijze van informatieverschaffing de oordeelsvorming van beleggingsanalisten kan beïnvloeden komt naar voren in de analyserapporten uitgebracht door Amro Beleggingsresearch. ${ }^{8}$ In januari werd gemeld dat de stijging van het resultaat uit gewone bedrijfsuitoefening over 1987 met $17 \%$ geheel conform de verwachtingen was. Daarbij werd - noodzakelijkerwijs - geen rekening gehouden met het jaareffect van de stelselwijziging. Wel werd melding gemaakt van het cumulatieve effect van de stelselwijziging. In maart paste de beleggingsanalist zijn oordeel echter aan en sprak over een bij de verwachtingen achterblijvende winstgroei. Hij gaf daarbij aan dat ongeveer de helft van de winstgroei een gevolg was van de stelselwijziging.

\section{VNU 1990}

De stelselwijziging van VNU in haar jaarrekening over 1990 betreft eveneens de verwerking van WIR-premies. Er is uitsluitend sprake van een cumulatief effect dat als buitengewone bate wordt verantwoord. Als gevolg van de stelselwijziging is het gepresenteerde nettoresultaat over 1990 ruim $20 \%$ hoger (zie tabel 2 ).

In januari 1991 publiceerde VNU voorlopige jaarcijfers, gevolgd door de definitieve jaarcijfers in maart 1991. In beide gevallen werd melding gemaakt van het feit dat de winstdaling (circa $7 \%$ ) vooral een gevolg was van voorzieningen getroffen voor reorganisaties. Op de stelselwijziging werd echter niet expliciet ingegaan. Informatie omtrent de stelselwijziging en de invloed daarvan op de gepresenteerde cijfers werd voor het eerst 
verschaft in de officiële jaarrekening die in april 1991 werd gepubliceerd. Het bleek dat de als buitengewone last verantwoorde reorganisatiekosten voor een groot deel werden gecompenseerd door de buitengewone bate als gevolg van de stelselwijziging; zonder stelselwijziging zou de nettowinst ten opzichte van het voorafgaande jaar niet met $7 \%$ maar met $23 \%$ zijn gedaald.

Op basis van de persberichten inzake de voorlopige respectievelijk definitieve jaarcijfers werd door een aantal beleggingsanalisten de omvang van de voorziening voor reorganisaties geschat. De schattingen weken evenwel in belangrijke mate af van de werkelijkheid, doordat adequate informatie omtrent de stelselwijziging in de desbetreffende persberichten ontbrak. ${ }^{9}$ Een financieel journalist kwalificeerde de handelwijze van VNU in een artikel naar aanleiding van de publikatie van de officiële jaarrekening als 'een opvallende manoeuvre'. ${ }^{10}$

\section{KLM $1989 / 90$}

De stelselwijziging van KLM in haar jaarrekening over 1989/90 heeft betrekking op de behandeling van koersverschillen op langlopende schulden en financiële vaste activa. Evenals bij VNU is er sprake van een cumulatief effect dat als buitengewone bate wordt verantwoord. Door de stelselwijziging is het nettoresultaat over het boekjaar 1989/90 met ongeveer 16\% toegenomen (zie tabel 2).

In mei 1990 maakte KLM voorlopige jaarcijfers bekend. In het persbericht werd vermeld dat het eindresultaat door een aantal - per saldo voordelige - incidentele factoren werd beïnvloed zonder dat specifiek werd ingegaan op de stelselwijziging. Dat laatste gebeurde wel in het enkele weken later uitgebrachte persbericht inzake de definitieve jaarcijfers, alsook in de officiële jaarrekening die in juli 1990 werd gepubliceerd.

Door een beleggingsanalist van de ABN Bank werd naar aanleiding van het in mei uitgebrachte persbericht - waarin alleen het nettoresultaat stond vermeld - een schatting gemaakt van het resultaat uit gewone bedrijfsuitoefening. Als gevolg van het ontbreken van informatie omtrent de stelselwijziging was deze schatting te hoog. In zijn analyserapport naar aanleiding van de bekendmaking van de definitieve jaarcijfers sprak de desbetreffende beleggingsanalist van teleurstellende resultaten. ${ }^{11}$ Een beleggingsanalist van Amro Beleggingsre- search kwalificeerde de buitengewone bate als gevolg van de stelselwijziging als een 'grote verrassing'. ${ }^{12}$

Uit bovenstaande casusbeschrijvingen blijkt dat beleggingsanalisten door een incomplete of inadequate informatieverschaffing omtrent stelselwijzigingen bij de bekendmaking van voorlopige of definitieve jaarcijfers aanvankelijk op het verkeerde been worden gezet. Het is aannemelijk dat ook de oordeelsvorming van andere beleggingsanalisten, die in hun analyserapporten niet expliciet ingaan op de wijze van informatieverschaffing door de onderneming, is beïnvloed. Het is verder plausibel om te veronderstellen dat in de gevallen waarin zelfs de uiteindelijke informatieverschaffing in de officiële jaarrekening als incompleet of inadequaat kan worden aangemerkt, de oordeelsvorming van beleggingsanalisten die de stelselwijziging niet signaleren waarschijnlijk wordt beïnvloed.

\section{Slotbeschouwing}

In onderhavige studie is onderzocht of het fixatieniveau van beleggingsanalisten afhankelijk is van de mate waarin een onderneming in haar jaarrekening informatie verschaft ten aanzien van de doorgevoerde stelselwijziging, het moment waarop de stelselwijziging voor het eerst wordt aangekondigd c.q. bekendgemaakt, de aard van de stelselwijziging en de werkgever van de beleggingsanalist. De mate van informatieverschaffing omtrent de stelselwijziging en de aard van de stelselwijziging blijken belangrijke determinanten te zijn van het fixatieniveau van beleggingsanalisten. Verder komt uit het onderzoek naar voren dat financieel journalisten stelselwijzigingen uitgebreider bespreken dan beleggingsanalisten werkzaam bij banken en effectenhuizen.

Het feit dat de kwaliteit van de informatieverschaffing in de jaarrekening een belangrijke determinant is van het fixatieniveau van beleggingsanalisten betekent dat een adequate informatieverschaffing in de jaarrekening omtrent doorgevoerde stelselwijzigingen van groot belang is. Gezien de intermediaire rol die beleggingsanalisten op de kapitaalmarkt vervullen, geldt dat niet alleen voor de beleggingsanalisten zelf maar ook voor de institutionele en particuliere beleggers die bij hun oordeels- en besluitvorming vertrouwen op de analyserapporten van beleggingsanalisten. Het verdient daarbij aanbeveling alle informatie 
omtrent stelselwijzigingen prominent in de toelichting op de jaarrekening te presenteren, bijvoorbeeld in een aparte rubriek 'stelselwijziging' onder de grondslagen van waardering en resultaatbepaling.

Het is echter niet alleen van belang dat in de jaarrekening waarin de stelselwijziging feitelijk is doorgevoerd adequate informatie wordt verschaft. maar ook reeds vóór de publikatie van de officiële jaarrekening is informatie omtrent stelselwijzigingen van belang. Het blijkt immers dat beleggingsanalisten bij de bekendmaking van voorlopige of definitieve jaarcijfers aanvankelijk op het verkeerde been worden gezet door een incomplete of inadequate informatieverschaffing omtrent stelselwijzigingen. Hoewel beleggingsanalisten in een later stadium vaak in de gelegenheid zullen zijn om hun oordeelsvorming bij te stellen - namelijk wanneer de informatieverschaffing in de officiële jaarrekening uiteindelijk adequaat is - is een dergelijke situatie ongewensı. Vanwege de nieuwswaarde staan voorlopige c.q. definitieve jaarcijfers op het moment van publikatie over het algemeen meer in de belangstelling dan de officiële jaarrekening. Het verdient dan ook aanbeveling om reeds in de persberichten inzake voorlopige c.q. definitieve jaarcijfers onomwonden aan te geven wat de invloed van een stelselwijziging is op de daarin opgenomen cijfers. Hetzelfde geldt - uiteraard - ook voor kwartaalverslagen en halfjaarlijkse verslagen indien bij de publikatie van deze verslagen reeds tot stelselwijziging is besloten.

\section{Suggestie voor verder onderzoek}

In de hiervoor besproken studies van Abdelkhalik \& Keller (1979) en Feenstra (1985) is onderzocht in welke mate het oordeel van beleggingsanalisten wordt beimloed door bepaalde stelselwijzigingen. Op basis van de analyserapporten was dat evenwel niet mogelijk, omdat het oordeel van beleggingsanalisten door tal van factoren wordt bepaald. In onderhavige studie is onderzocht in welke mate beleggingsanalisten stelselwijzigingen signaleren en de cijfermatige effecten daarian in hun analyserapporten bespreken. Het zal duidelijk zijn dat de interne validiteit van deze studie lager is dan die van de eerdere studies. De externe validiteit van de studie daarentegen is hoger. Het betreft immers geen experiment waarin beleggingsanalisten met min of meer gekunstelde cases worden geconfronteerd. Verder onderzoek is evenwel geboden. De mate waarin het oordeel van beleggingsanalisten in werkelijkheid wordt beïnvloed door stelselwijzigingen, kan bijvoorbeeld worden onderzocht door bestudering van de relatie tussen de effecten van stelselwijzigingen op de door ondernemingen gepresenteerde winstcijfers en de winstvoorspellingen van beleggingsanalisten.

\section{I T ERATU U R}

Abdel-khalik, A.R. \& Keller, T.F., (1979) Earnings or Cash Flows: An Experiment on Functional Fixation and the Valuation of the Firm. Sarasota (Florida): American Accounting Association.

Abdel-khalik, A.R. \& Mckeown, J.C., (1978), 'Understanding Accounting Changes in an Efficient Market: Evidence of Differential Reaction', The Accounting Review, oktober, pp. 851-68.

Archibald, T.R., (1972), 'Stock Market Reaction to the Depreciation Switch-Back', The Accounting Review, januari, pp. 22-30.

Ball, R., (1972), 'Changes in Accounting Techniques and Stock Prices', Journal of Accounting Research, supplement, pp. 1-38.

Biddle, G.C. \& Lindahl, F.W., (1982), 'Stock Price Reactions to LIFO Adoptions: The Association Between Excess Returns and LIFO Tax Savings', Journal of Accounting Research, herfst, pp. 551-588

Chang, L.S. \& Most, K.S., (1985), The Perceived Usefulness of Financial Statements for Investors' Decisions. Miami: Florida International University Press.

Feenstra, D.W., (1985), Oordeelsvorming rond de externe berichtgeving. Groningen: Wolters-Noordhoff

Hoogendoorn, M.N., (1990), Stelselwijzigingen in de jaarrekening. Groningen: Wolters-Noordhoff.

Kaplan, R.S. \& Roll, R., (1972), 'Investor Evaluation of Accounting Information: Some Empirical Evidence', The Journal of Business, april, pp. 225-257.

Ricks, W.E., (1982), 'The Market's Response to the 1974 LIFO Adoptions', Journal of Accounting Research, herfst, pp. 367-387

Stevenson, F.L., (1987), 'New Evidence on LIFO Adoptions: The Effects of More Precise Event Dates', Journal of Accounting Research, herfst, pp. 306-316.

Vergoossen, R.G.A., (1993), 'The Use and Perceived Importance of Annual Reports by Investment Analysts in the Netherlands', The European Accounting Review, no. 2, pp. 219-244 en no. 3, pp. 579-580.

Vergoossen, R.G.A., (1994), Accounting Changes and the Use of Financial Statements: A Study among Investment Analysts. Katwijk: All In/Verhagen. 


\section{NOTEN}

1 Ten tijde van het onderzoek telde de VBA ruim 500 leden. De respons was $43 \%$.

2 Zie voor een uitgebreide bespreking Vergoossen (1994, hoofdstuk 6).

3 In 1992 waren de hier bedoelde banken en effectenhuizen verantwoordelijk voor ongeveer $70 \%$ van de effectieve aandelenomzet op de Amsterdamse effectenbeurs (zie persbericht Amsterdamse effectenbeurs d.d. 4 maart 1993). De in het onderzoek betrokken beleggingsanalisten kunnen dan ook als representatief worden beschouwd voor de gehele populatie van beleggingsanalisten werkzaam bij banken en effectenhuizen.

4 De stelselwijzigingen zijn geselecteerd uit de jaarrekeningen over de boekjaren 1987-1991 van niet-financiële ondernemingen waarvan de aandelen behoren tot de 40 meest actief verhandelde fondsen van de Amsterdamse effectenbeurs. In totaal zijn 144 jaarrekeningen onderzocht. Deze jaarrekeningen bevatten 19 zichtbare stelselwijzigingen met een belangrijke invloed op eigen vermogen en/of nettoresultaat (in beginsel ten minste $5 \%$ ). Drie stelselwijzigingen zijn echter niet in het onderzoek opgenomen vanwege een gebrek aan bruikbare analyserapporten.

5 Deze informatie-elementen kunnen direct worden afgeleid uit artikel 384 lid 6 en artikel 363 lid 5, Burgerlijk Wetboek, Boek 2. De Raad voor de Jaarverslaggeving bepaalt voorts dat in meerjarenoverzichten stelselwijzigingen ten minste dienen te worden aangegeven en dat de kwantitatieve invloed van stelselwijzigingen op volgende boekjaren dient te worden vermeld indien verwacht kan worden dat deze belangrijk zal zijn. Bij de bepaling van de informatieverschaffingsindex zijn deze informatie-elementen niet meegenomen, omdat die niet direct kunnen worden afgeleid uit genoemde wetsartikelen. Bovendien zal het in de praktijk vaak moeilijk zijn informatie te verstrekken omtrent de invloed van stelselwijzigingen op volgende boekjaren.

6 Andere denkbare determinanten van het fixatieniveau van beleggingsanalisten zijn de materialiteit van de stelselwijziging, de tijd besteed aan het schrijven van het analyserapport, het opleidingsniveau van de beleggingsanalist en de werkervaring van de beleggingsanalist. Het is evenwel niet mogelijk gebleken deze determinanten aan de hand van de analyserapporten op bevredigende wijze te onderzoeken.

7 De bevindingen worden bevestigd wanneer de overige stelselwijzigingen worden beschouwd als afzonderlijke categorieën $\left(\chi^{2}: 53,588\right.$; p: 0,000). Wordt daarbij rekening gehouden met de mate van informatieverschaffing dan bedraagt $\chi^{2}$ 12,031 en de $p$-waarde 0,034.

8 Amro Beleggingsresearch, Aandelen Commentaar d.d. 18 januari 1988, 7 maart 1988 en 14 april 1988.

9 Zie rapporten van Amro Beleggingsresearch ( 9 januari 1991), Bank Mees \& Hope (18 maart 1991) en Williams de Broë (12 februari 1991).

10 Zie Beleggers Belangen d.d. 13 april 1991, VNU: andere gedaante.

11 ABN Bank, Dutch Company News Nr. 66 d.d. 25 mei 1990 en Nr. 70 d.d. 14 juni 1990.

12 Amro Beleggingsresearch, Aandelen Commentaar d.d 22 juni 1990. 